\title{
Politik Beceri ve Psikolojik Sermaye Arasındaki İlişkinin Öğretmen Görüşlerine Göre İncelenmesi
}

\section{Investigating the Relationship between Political Skill and Psychological Capital According to Opinions of Teachers}

\author{
Murat ÖZDEMIR*, Safiye Çiğdem GÖREN**
}

\begin{abstract}
ÖZ: Bu araştırmada psikolojik sermaye ve politik beceri arasındaki ilişkinin nasıl olduğu, öğretmen görüşlerine dayalı olarak analiz edilmiştir. Araştırmada ayrıca öğretmenlerin sahip oldukları psikolojik sermayenin, politik beceriyi ne oranda açıkladığı da incelenmiştir. Araştırmaya 2013-2014 eğitim öğretim yılının ikinci döneminde Ankara ili Altındağ ilçelesindeki 15 ilkokul ve ortaokulda görev yapmakta olan 325 öğretmen katılmıştır. Veriler Politik Beceri Envanteri ve Psikolojik Sermaye Ölçeği ile elde edilmiştir. Katılımcılardan toplanan veriler aritmetik ortalama, standart sapma ve yüzdelik değer gibi betimsel istatistiklerin yanı sıra doğrulayıcı faktör analizi (DFA), Pearson korelasyon ve hiyerarşik çoklu regresyon ile çözümlenmiştir. Analiz sonuçları öğretmenlerin politik beceri ve psikolojik sermaye algılarının görece yüksek olduğunu göstermiştir. Araştırmada psikolojik sermaye ile politik beceriler arasında pozitif yönde, orta düzeyde ve istatistiksel olarak anlamlı korelasyon olduğu saptanmıştır. Ayrıca elde edilen bulgular, öğretmenlerin demografik özelliklerinin politik becerileri üzerinde etkili olmadığını ancak psikolojik sermaye alt boyutlarının ayrı ayrı politik becerinin anlamlı birer yordayıcısı olduğunu göstermiştir.
\end{abstract}

Anahtar sözcükler: Politik beceri, psikolojik sermaye, öğretmen

\begin{abstract}
In this study the relationship between political skill and psychological capital was investigated according to opinions of teachers. This study also investigated how teachers' psychological capital influences their political skill. The study was conducted with 325 teachers working in 15 primary and secondary schools in the district of Ankara Altındağ. Within this scope, Psychological Capital Questionnaire and Political Skill Inventory were applied to participants. The scales gathered from participants analyzed via mean, standard deviation, Pearson correlation and hierarchical multiple regression. After the analysis, it was found that the level of teachers' political skill and psychological capital were relatively high. It was determined that there was a positive, medium level and statistically significant relation between political skill and psychological capital. Besides, the results showed that demographic features of teachers didn't affect political skill, but all sub-dimensions of psychological capital were significant predictors of political skill.
\end{abstract}

Keywords: Political skill, psychological capital, teacher

\section{GİRIŞ}

Öğrenci başarısında kişisel, ailevi ve sosyo-ekonomik faktörler kadar, okulla ilgili faktörler de önemlidir. Öğrenci başarısı ile ilişkili okul içi faktörlerin başında ise öğretmenler yer almaktadır. Bu çerçevede hizmet öncesi ve hizmet içi eğitim, mesleki deneyim ve kişilik özelliklerinin, öğretmen etkililiği ile ilişkili olduğu rapor edilmiştir (Ehrenberg ve Brewer, 1994; King, 2003; Wayne ve Youngs, 2003). Öğrenciler üzerindeki etkisi nedeniyle, öğretmen özelliklerinin son yıllarda artan oranda incelenmeye başladığ 1 da görülmektedir (Jina, 2002). Öğretmenlerin kiş̧ilik özellikleri ile ilgili olarak literatürde ağırlıklı olarak öz-yeterlik (Woolfolk ve Hoy,1990), öğretmen yılmazlığı (resiliency) (Howard ve Johnson, 2004) ve denetim odağı

\footnotetext{
*Doç. Dr., Hacettepe Üniversitesi, Eğitim Fakültesi, Eğitim Bilimleri Bölümü, Ankara-Türkiye, mrtozdem@gmail.com

** Doktora Öğrencisi, Hacettepe Üniversitesi, Eğitim Fakültesi, Eğitim Bilimleri Bölümü, Ankara-Türkiye, scgoren@hotmail.com
} 
(Parkay, Greenwood, Olejnik, ve Proller,1990) gibi değişkenlerin incelendiği görülmektedir. Ancak öğretmen özelliklerinin okulun genel ikliminden bağımsız düşünülerek ele alınması ve incelenmesi, öğretmenlerin davranışlarını ve performanslarını anlamakta yetersiz kalabilmektedir. Çünkü öğretmenler okullarda kendilerini kuşatan kültürel ve mikro-politik bir çevre içerisinde davranmaktadır. Bu kapsamda öğretmen davranışlarının, okulun mikro-politik iklimi ve kültürü bağlamında incelenmesi önem taşımaktadır.

Mikropolitika, okulu güç ilişkileri temelinde biçimlenen bir örgüt olarak gören kuramsal bir yaklaşımdır (Blase, 1991; Innaconne, 1975). Okulun, mikropolitikanın hâkim olduğu bir örgüt olduğu varsayımına dayalı olarak, öğretmenlerin de okulun politik aktörleri olduğu öne sürülebilir. Bu bağlamda, öğretmenlerin kişisel ve örgütsel amaçların başarılmasında politik becerilere sahip olmaları gerekmektedir. Nitekim ilgili araştırmalar, politik beceri düzeyi yüksek örgüt üyelerinin kişisel ve örgütsel amaçları daha etkili başardıklarını ortaya koymaktadır (Ahearn ve diğerleri, 2004; Cingöz, 2013; Douglas ve Ammeter, 2004).

\subsection{Politik Davranıș}

Politik becerinin kavramsallaştırılması sürecine Mayes ve Allen (1977), Pfeffer (1981) ve Mintzberg (1985) gibi bilim insanlarının önemli katkıları olmuştur. Bu yazarlar temel olarak politik davranışların, örgütsel yaşamın önemli bir yönü olduğu görüşünü savunmuşlardır. Politik davranış, "çalışanın resmi rolünün bir parçası olarak görülmeyen ancak onu etkileyen veya etkilemeye çalışan, örgüt içerisinde avantajların ve dezavantajların dağıtımına ilişkin faaliyetlerden oluşan bir süreç" olarak tanımlanmaktadır (Robbins ve Judge, 2013, s. 431). Bu çerçevede eğitim öğretim sürecinin planlandığ 1 , uygulandığ 1 ve değerlendirildiği eğitim örgütlerinde de öğretmenlerin örgütsel ve kişisel amaçları başarmak için politik davranışlar sergiledikleri düşünülebilir. Literatürde örgütsel muhalefet, haber uçurma (whistleblowing), örgütsel çatışma, örgütsel sessizlik ve güç kullanımı gibi davranışların okullarda da sergilendiğine yönelik ampirik bulgularlar bulunmaktadır (Altınkurt ve Y1lmaz, 2012; Nartgün ve Kartal, 2013; Özdemir, 2011, 2013a, 2013b). Tüm bu davranış örüntülerinin varlığ1, okulun politik bir arena olduğu yönündeki görüşleri destekler niteliktedir.

Tüm örgütlerde olduğu gibi okullarda da gözlenen politik davranışların genel amacı, örgüt üyesinin örgüt ortamındaki kişisel kontrolünü görece koruması ve güçlendirmesidir. Böylece örgüt üyesi, örgütsel yaşama özgü çeşitli stres kaynaklarının olumsuz etkilerini daha az hissetmektedir (Harrell-Cook, Ferris ve Dulebohn, 1999). Bununla birlikte iş yerlerinde çalışanların politik davranışlar sergilemesinin bir diğer önemli nedeni kişisel faktörler olabilir. Özellikle bazı kişilik tiplerine sahip çalışanların bu tür davranışları sıcça sergiledikleri ifade edilmektedir. Örneğin politik davranışların çoğunlukla içsel kontrole sahip ve yüksek düzeyde güç isteyen çalışanlarca sergilendiği belirtilmektedir. Diğer yandan çalışanların örgüte yapmış oldukları yatırım, örgüte özgü kimi alternatiflerin farkında olmaları ve başarı beklentileri gibi etmenler de politik davranışların sergilenmesinin temel nedenleri arasında sıralanmaktadır (Robbins ve Judge, 2013).

\subsection{Politik Beceri}

Öğretmenlerin sergiledikleri politik davranışların, beklenen sonuca ulaşması ise politik beceri ile ilişkilidir. Politik beceri (political skill) "bir çalışanın diğer çalışanlar hakkındaki bilgisini kullanarak onları, kendisinin ya da örgütün amaçları doğrultusunda davranmaları yönünde etkileme yeteneği” olarak tanımlanmaktadır (Ahearn, Ferris, Hochwarter, Douglas ve Ammeter, 2004, s. 311). Dolayısıyla politik beceri ikna, manipülasyon ve müzakere gibi bir takım sosyal beceriyi de içine alan politik bir davranış olarak ele alınmakta ve incelenmektedir 
(Mintzberg, 1983'den akt. Ferris ve diğerleri, 2005, s, 127). Politik beceri düzeyi yüksek çalışanlar, iş yerindeki değişimlere çabuk uyum sağlayabilmekte, diğerlerine samimi ve içten davranarak onların desteğini ve güvenini kazanmakta ve böylece onları etkileyerek kontrol altına alabilmektedir. Politik beceriye sahip çalışanlar söz konusu etkiyi ve kontrolü, iş yerinde açık ve aleni davranışlar sergilemekten daha çok, bunu diğerlerine hissettirmeden sağlayabilmektedirler (Ferris ve diğerleri, 2005).

Politik becerinin dört temel boyuttan oluşmaktadır. Bunlardan biri sosyal zekâdır. Buna göre politik becerisi yüksek çalışanlar başkalarını dikkatli bir şekilde gözlemlemekte ve çeşitli sosyal ortamlara kendilerini çabuk uyarlayabilmektedirler. Bu kapsamda bu kişiler ayrıca çok yüksek düzeyde bir sezgi gücüne de sahiptirler. Sosyal zekâsı yüksek kişiler aynı zamanda sosyal ortamları ve kişilerarası ilişkileri çok iyi okuma becerisine de sahiptirler. Politik becerinin bir diğer boyutu ise kişilerarası etkidir. Kişilerarası etki gücü yüksek çalışanlar çevrelerindeki kişiler üzerinde etki gösterme konusunda ustadırlar. Bu çerçevede bu kişiler, başkalarının davranışlarını belli bir yönde etkileyebilme kapasitesi taşımaktadırlar. Politik becerinin bir başka boyutunu ise ilişki ă̆ kurma becerisi oluşturmaktadır. Buna göre bu kişiler çok kolay bir şekilde yeni arkadaşlar edinebilmekte ve bu arkadaşlıklara dayalı olarak çeşitli amaçlara dönük örgüt içi koalisyonlar kurabilmektedirler. Politik becerinin dördüncü boyutu ise samimi görünmedir. Politik becerisi yüksek kişiler başkaları tarafından erdemli, dürüst, samimi ve içi dışı bir olarak algılanmaktadırlar. Samimi görünme, diğerlerini belli yönde harekete geçirme bakımından büyük önem taşımaktadır. Çünkü art niyet taşıdığına ilişkin bir izlenim doğuran kişiler, başkalarını etkileme gücünü kaybedecektir (Atay, 2010; Blass ve Ferris, 2007; Ferris ve diğerleri, 2005).

İlgili yazın taramalarında, politik davranışlar ve bu kapsamda politik becerilerin örgütsel yaşamdaki görünümlerine odaklanan ampirik çalışmaların son yıllarda artış eğilimine girdiği görülmektedir (Ahearn ve diğerleri, 2004; Cingöz, 2013; Douglas ve Ammeter, 2004; Treadway ve diğerleri, 2007). Ancak bu çalışmalar genel olarak eğitim dışındaki kamu ve özel sektör örgütleri üzerinde yürütülmüştür. Okullarda görev yapan öğretmenlerin politik beceri düzeylerine odaklanan çalışmalar ise sinırlıdır (Taliadorou ve Pashiardis, 2012). Dolayısıyla öğretmenlerin politik becerilerinin incelenmesinin alan yazındaki sınırlı çalışmalara katkı sunabileceği düşünülmektedir. Bu çalışmada, ilköğretim okullarında görev yapmakta olan öğretmenlerin politik becerilerine odaklanılmıştır. Bu kapsamda, öğretmenlerin politik becerileri, onların psikolojik sermayeleri ile birlikte analiz edilmiştir.

\subsection{Psikolojik Sermaye}

Psikolojik sermaye, tecrübeye dayanan ödüllerin (bilgi, beceri, yetenek gelişimi) kazanımı sonucunda, bugün ve geleceğe yönelik bireysel faydaların elde edilebileceğine ilişkin bütüncül ruhsal durum olarak tanımlanmaktadır (Kersting, 2003'den akt. Erkuş ve Fındıklı, 2013). Pozitif psikolojinin örgüt yaşamındaki yansıması olarak nitelendirilebilecek olan pozitif örgütsel davranış kavramı, psikolojik sermayenin kavramsallaştırılmasına katkı sunmuştur (Güler, 2009'den akt. Erkmen ve Esen, 2012).

Bireyin gelişimine dair pozitif psikolojik durumu ile ilgili olan psikolojik sermayenin çeşitli tanımları bulunmaktadır. Bu tanımların birinde psikolojik sermaye, zor görevlerde başarıya ulaşmak için gerekli çabayı göstermeyi sağlayacak güvene ya da başka bir deyişle özyeterliğe sahip olma durumu olarak ele alınmaktadır. Başka bir tanıma göre ise psikolojik sermaye şimdiki zamanda ve gelecekte başarılı olabilme ihtimaline dair pozitif yönde beklenti ya da başka bir deyişle iyimser olma durumudur. Ayrıca psikolojik sermayenin, hedeflere ulaşma noktasında azimli olmak ve başarıyı elde etmeye dönük yeni yollara yönelebilme ya da başka bir deyişle umut taşıma olarak da tanımlandığı görülmektedir. Son olarak psikolojik sermayenin, 
problemlere ya da olası sıkıntılarla yüz yüze kalındığında kendini toparlayabilme ve bu noktada 1srarcı bir tutum sergileyebilme, başka bir deyişle dayanıklı olabilme noktasında 1srarcı bir tutum sergileyebilme ya da dayanıklı olabilme olarak kavramsallaştırıldı̆̆ı söylenebilir (Luthans, Vogelgesang ve Lester, 2006'den akt. Keser ve Kocabaş, 2014.)

Görüldüğ̈̈ üzere psikolojik sermayenin özyeterlik, iyimserlik, umut ve dayanıklllı olmak üzere dört temel yönü bulunmaktadır. Özyeterlik, kişinin motivasyonunu ve bilişsel kaynaklarını, hayatındaki olayları kontrol edecek şekilde kullanması ve yaşamında karşılaştığı sorunları çözebileceğine dair inancıdır (Stajkovic ve Luthans, 1998'den akt. Keleş, 2011). Bireyin işini yaparken ve çalışırken sahip olduğu yeteneklere karşı pozitif inançları olarak da tanımlanmaktadır (Stajkovic, Luthans, 1998'den akt. Erkuş ve Fındıkl1, 2013). İyimserlik ise gelecekte iyi şeyler olacağı beklentisi olarak tanımlanabilir (Carver, 2002'den akt. Keser ve Kocabaş, 2014). Aynı zamanda, bireylerin olumlu olayları içsel, kalıcı ve yaygın nedenlerle ilişkilendirirken, olumsuz olayları dışsal, geçici ve belirli koşullara bağlamalarıyla ilgilidir şeklinde de tanımlanmıştır (Seligman, Csikszentmihalyi, 2000'den akt. Erkuş ve Fındıklı, 2013). Psikolojik sermayenin üçüncü boyutu olan umut ise etkileşimli biçimde (1) temsil (amaca odaklanmış enerji) ile (2) metotlardan (amaçları karşılaması planlanan) ortaya çıkan ve başarı duygusuna dayanan pozitif bir durum olarak açıklamaktadır (Snyder, 2000'den akt. Çetin ve Basım, 2012). Son olarak dayanıklılık kişinin birçok olumsuz durumla (engel, belirsizlik) baş etme ve başarılı olma yeteneği olarak görülmektedir (Luthans ve diğerleri, 2006). Dayanıklılık aynı zamanda, güçlük, belirsizlik, çatışma, başarısızlık gibi olumsuz durumlar karşısında olumlu değişim ve gelişim gösterebilme, artan sorumluluklarla beraber esnek davranabilme olarak tanımlanmaktadır (Masten, 2001, Luthans, 2002'den akt. Erkuş ve Fındıkl1, 2013).

Alan yazın taramalarında psikolojik sermayenin çeşitli yönlerden incelendiği görülmektedir. Bu çalışmalarda ağırlıklı olarak psikolojik sermayenin ne olduğu ve psikolojik sermayenin örgütler üzerindeki etkileri incelenmiştir (Keleş, 2011). Bununla birlikte psikolojik sermayenin örgütsel çıktılarla olan ilişkisinin de araştırıldığı anlaşılmaktadır. Ayrıca psikolojik sermaye ile iş doyumu arasındaki ilişkilerin yoğun olarak incelendiği de görülmektedir (Akçay, 2012; Erkuş ve Findıkl1, 2013; Kaplan ve Biçkes, 2013; Özer, Topaloğlu ve Özmen, 2013). Bununla birlikte sınırlı da olsa psikolojik sermayenin tükenmişlikle olan ilişkisi de incelenmiştir (Çetin, Şeşen ve Basım, 2013). Ancak eğitim örgütlerinde görev yapan öğretmenlerin psikolojik sermayelerine odaklanan çalışmaların oldukça sınırlı olduğu görülmüştür. Keser ve Kocabaş'ın (2014) ilköğretim okulu yöneticilerinin otantik liderlik ve psikolojik sermaye özelliklerini karşılaştırdıkları çalışma bunun bir örneğidir. Diğer yandan, alanyazında psikolojik sermaye ve politik beceri arasındaki ilişkiyi inceleyen çalışmalar da oldukça sınırlıdır (Oruç ve Özen Kutanis, 2015). Oysa ki, psikolojik sermayenin örgütte rekabet üstünlüğü sağladığı belirtilmektedir (Luthans, Luthans ve Luthans, 2004'den akt. Özen Kutanis ve Oruç, 2014). Benzer şekilde, politik becerinin de örgütteki güç ilişkileri ile ilgili olduğu düşünüldüğünde psikolojik sermaye ile ilişkili olabileceği akla gelmektedir. Bireylerin kişisel ya da örgütsel amaçlarını gerçekleştirmek için kullandıkları politik becerilerin, bireylerin güçlü yanlarını ortaya çıkarmaya yönelik özellikleri olan psikolojik sermayeden etkilenmesi olasıdır. Dolayısıyla bu çalışmada psikolojik sermaye ve politik beceri arasındaki ilişkinin nasıl olduğu, öğretmen görüşlerine dayalı olarak incelenmiştir. Bu kapsamda araştırmada aşağıdaki sorulara yanıt aranmıştır.

1. Öğretmenler ne düzeyde politik beceriye ve psikolojik sermayeye sahiptir?

2. Politik beceri ve psikolojik sermaye arasında anlamlı bir ilişki var mıdır?

3. Cinsiyet, medeni durum, eğitim durumu ve kıdem politik becerideki değişkenliğin ne kadarını açıklamaktadır?

4. Psikolojik sermaye, politik becerideki değişkenliğin ne kadarını açıklamaktadır? 


\section{YÖNTEM}

Öğretmenlerin politik beceri düzeylerinin psikolojik sermaye ve boyutları ile olan ilişkisini açıklamayı amaçlayan bu çalışma, tarama modelinde desenlenmiştir. Bu kapsamda araştırma verileri nicel bir yaklaşımla çözümlenmiştir.

\section{1. Çalışma Grubu}

$\mathrm{Bu}$ araştırma, 2013-2014 eğitim öğretim yılının ikinci döneminde Ankara ili Altındă̆ ilçesindeki 15 ilkokul ve ortaokulda görev yapmakta olan 325 öğretmenin gönüllü katılımı ile gerçekleşmiş̧ir.

Tablo 1. Katılımcıların demografik özellikleri

\begin{tabular}{llcc}
\hline & & $\mathbf{n}$ & \% \\
\hline Cinsiyet & Kadın & 226 & 69,5 \\
& Erkek & 99 & 30,5 \\
Eğitim Durumu & Lisans & 282 & 86,8 \\
& Lisansüstü & 43 & 13,2 \\
Medeni Durum & Evli & 242 & 74,5 \\
& Bekâr & 83 & 25,5 \\
& $1-5$ yll & 77 & 23,7 \\
Kıdem & $6-10$ yıl & 69 & 21,2 \\
& $11-15$ yll & 73 & 22,5 \\
& $16-20$ yıl & 57 & 17,5 \\
& 21 y1l ve üzeri & 49 & 15,1 \\
\hline
\end{tabular}

Katılımcı öğretmenler 21-60 yaş aralığında olup, yaş ortalamaları 35,68' dir. Tablo 1'de de görüldüğü gibi, katılımcıların 226'sı kadın (\% 69,5), 99'u erkektir (\%30,5). Katılımcıların 282'si lisans $(\% 86,8), 43$ 'ü lisansüstü $(\% 13,2)$ mezunudur. Bununla birlikte kat1lımcıların 242'si evli (\%74,5), 83'ü bekârdır (\%25,5). Katılımcı öğretmenlerin 77'si 1-5 yıl (\%23,7), 69'u 6-10 yıl $(\% 21,2), 73$ 'ü 11-15 y1l $(\% 22,5), 57$ 'si $16-20$ yıl $(\% 17,5)$ ve 49 'u 21 yıl ve üzeri $(\% 15,1)$ mesleki k1deme sahiptir.

\subsection{Veri Toplama Araçları}

\subsubsection{Politik beceri envanteri}

Katılımcıların politik beceri düzeylerini belirlemek için Ferris ve diğerleri (2005) tarafından geliştirilmiş olan Politik Beceri Envanteri (PBE) kullanılmıştır. PBE toplam on sekiz madde ve İlişki A ̆̆ Kurma Becerisi (6 madde), Kişilerarası Etki (4 madde), Sosyal Zeka (5 madde) ve Samimi Görünme (3 madde) başlıkları altında dört boyuttan oluşmaktadır. Ölçek, alt boyutlarının yanı sıra toplam puanı ile de değerlendirilebilmektedir. PBE ‘hiç katılmıyorum' ile 'tamamen katılıyorum' arasında değer alan yedi dereceli Likert tipi bir ölçektir. Katılımcıların ölçekten yüksek puan alması, politik becerilerinin fazla olduğu şeklinde yorumlanırken, düşük puanlar, katılımcıların politik becerilerinin az olduğu şeklinde yorumlanmaktadır. PBE'de yer alan örnek maddeler arasında 'İş yerinde sözü geçen insanlarla bağlantı kurmakta iyiyim' ve 'Çoğu insanla samimiyet kurmak benim için çok kolay' yer almaktadır. PBE'nin geliştirilmesi sürecinde 350 katılımcının görüşlerinden yararlanılmıştır. PBE’nin orijinal çalışmasında Cronbach alfa değerleri Politik Beceri için .90, İlişki A $\breve{g}_{\imath}$ Kurma Becerisi için .87, Kişilerarası Etki için .78, Sosyal Zeka için .79 ve Samimi Görünme için .81 olarak hesaplanmıştır (Ferris ve diğerleri, 2005). Bu çalışmada da PBE'nin geçerlik ve güvenirlik çalışmaları, katılımcılar toplanan 325 ölçek üzerinde tekrar yapılmıştır. PBE'nin geçerliği doğrulayıcı faktör analizi ile (DFA) incelenmiştir. Bu kapsamda PBE'nin dört boyutlu yapısı test edilmiştir. DFA çalışması 
LISREL 8.8 versiyonu ile gerçekleştirilmiştir. Bu çalışma kapsamında yapılan hesaplamalar sonrasında PBE'nin dört boyutlu yapısının doğrulandığı ve orjinalindeki gibi aynı maddelerin aynı boyutlarda toplandığı görülmüştür; $\left[\chi^{2}=447.97 ; \mathrm{Sd}=126 ; \chi^{2} / \mathrm{Sd}=3.5 ; \mathrm{AGFI}=.82 ; \mathrm{GFI}=.87\right.$; $\mathrm{NFI}=.96 ; \mathrm{CFI}=.97 ; \mathrm{IFI}=.97 ; \mathrm{RMR}=.18 ; \mathrm{RMSEA}=.08]$ (Byrne \& Campbell, 1999; Kline, 2005). Mevcut araştırmada elde edilen uyum iyiliği sonuçları bir bütün olarak değerlendirildiğinde, PBE'nin dört boyutlu Türkçe formunun geçerli olduğu görülmüştür. Yapılan hesaplamalar sonrasında PBE'nin Cronbach alfa değerinin ise .94 olduğu görülmüştür.

\subsubsection{Psikolojik sermaye ölçeği}

Psikolojik sermaye düzeyinin ölçümü için Luthans, Avolio, Avey ve Norman (2007) tarafından geliştirilen Psikolojik Sermaye Ölçeği (PSÖ) kullanılmıştır. PSÖ, 24 madde ve özyeterlilik, umut, iyimserlik ve psikolojik dayanıklılık başlıkları altında dört boyuttan oluşmaktadır. Her boyut altı maddeden oluşmaktadır. Ölçek alt boyutlarının ayrı ayrı toplam puanının yanı sıra ölçek toplam puanı ile de değerlendirilebilmektedir. PSÖ'de yer alan maddeler arasında "Uzun dönemli bir problemi çözüm bulmak için analiz ederken kendimden eminimdir", "Her probleme ilişkin çok sayıda çözüm yolu bulunmaktadır", "Bu işte aynı anda birçok şeyin üstesinden gelebileceğimi hissediyorum" gibi maddeler bulunmaktadır. PSÖ, 'hiç katılmıyorum' ile 'tamamen katılıyorum' arasında değer alan altı dereceli Likert tipi bir ölçektir. Luthans ve diğerleri (2007) dört farklı örneklem üzerinde yaptıkları çalışmada, PSÖ’nün Cronbach Alfa değerlerini umut için $(0,72,0,75,0,80,0,76)$; psikolojik dayanıklılık için $(0,71$, $0,71,0,66,0,72)$; $z$ z yeterlilik için $(0,75,0,84,0,85,0,75)$; iyimserlik için $(0,74,0,69,0,76,0,79)$ ve ölçeğin bütünü için $(0,88,0,89,0,89,0,89)$ olarak bulmuşlardır. PSÖ'nün bu çalışmanın verileri için de geçerli ve güvenir olup olmadığ 1 tekrar incelenmiştir. DFA sonucunda elde edilen uyum indeksi değerleri şu şekildedir; $\left[\chi^{2}=681,56 ; \mathrm{Sd}=243 ; \chi^{2} / \mathrm{Sd}=2,8 ;\right.$ AGFI $=.82 ; \mathrm{GFI}=.85$; $\mathrm{NFI}=.96 ; \mathrm{CFI}=.97 ; \mathrm{IFI}=.97 ; \mathrm{RMR}=.09 ; \mathrm{RMSEA}=.07]$. Mevcut araştırmada elde edilen uyum iyiliği sonuçları bir bütün olarak değerlendirildiğinde, PSÖ'nün dört boyutlu yapısının geçerli olduğu kanaatine ulaşılmıştır. Yapılan analizler sonucunda PSÖ'nün Cronbach alfa değerinin ise .91 olduğu görülmüştür.

\subsection{Verilerin Analizi ve İşlemler}

Veri toplama araçları okul müdürlerinin izni alınmak sureti ile ders bitimlerinde araştırmacılar tarafından öğretmenlere bizzat uygulanmıştır. Araştırma verileri 2014 yılının Nisan, Mayıs ve Haziran aylarında toplanmıştır. Öğretmenler çalışmaya gönüllü olarak katılmışlardır. Veri toplama aracının doldurulma süresi yaklaşık olarak 15 dakika sürmüştür. Araştırmada katılımcılardan toplanan veriler aritmetik ortalama, standart sapma ve yüzdelik değer gibi betimsel istatistiklerin yanı sıra doğrulayıcı faktör analizi (DFA), Pearson korelasyon ve hiyerarşik çoklu regresyon teknikleri ile çözümlenmiş̧ir. Verilerin analizi öncesinde uç değer ve kayıp veri analizleri yapılmış, saptanan sorunlar giderilmiştir. Verilerin çok değişkenli analize uygunluğunu belirlemek amacıyla, normallik ve eş varyanslılık analizleri de yapılmıştır. Data setinin normalliği saçılma diagramı ile incelenmiştir. Saçılma diyagramında araştırma değişkenlerinin elips şeklinde bir dağılım gösterdiği belirlenmiştir. Bu veriye dayalı olarak data setinin normal dağılım gösterdiği ve doğrusallık özellikleri taşıdığı görülmüştür. Eşvaryanslılığın incelenmesi amacıyla ise varyans-kovaryans matrislerinden yararlanılmıştır. Yapılan testlerde Box M testi sonucu anlamlı çıkmamıştır $(p>.025)$. Çıkan sonucun manidar olmaması varyanskovaryans matrislerinin homojen olmadığı şeklinde yorumlanmıştır. Bu kapsamda araştırma verilerinin çok değişkenli analize uygun olduğu görülmüştür. 


\section{BULGULAR}

\subsection{Betimsel İstatistikler ve Değişkenler Arası Korelasyonlar}

Katılımcıların politik beceri ve psikolojik sermaye aritmetik puan ortalamaları ve standart sapma puanları ile değişkenler arası korelasyon katsayıları Tablo 2'de sunulmuştur.

Tablo 2. Değişkenlere ait betimsel istatistikler ve korelasyon katsayıları

\begin{tabular}{|c|c|c|c|c|c|c|c|c|c|c|}
\hline & 1 & 2 & 3 & 4 & 5 & 6 & 7 & 8 & 9 & 10 \\
\hline $1 \mathrm{PS}$ & - & & & & & & & & & \\
\hline $2 \mathrm{~PB}$ & $.606^{*}$ & - & & & & & & & & \\
\hline 3 İyimserlik & $.723^{*}$ & $.391^{*}$ & - & & & & & & & \\
\hline 4 P. Dayanıklılık & $.850^{*}$ & $.530^{*}$ & $.441^{*}$ & - & & & & & & \\
\hline 5 Umut & $.913^{*}$ & $.548^{*}$ & $.563^{*}$ & $.720^{*}$ & - & & & & & \\
\hline 6 Öz yeterlilik & $.890^{*}$ & $.574^{*}$ & $.486^{*}$ & $.729^{*}$ & $.765^{*}$ & - & & & & \\
\hline 7 İ. Ağ1 Kurma & $.484^{*}$ & $.873^{*}$ & $.287^{*}$ & $.435^{*}$ & $.448^{*}$ & $.457^{*}$ & - & & & \\
\hline 8 Kişilerarası Etki & $.478^{*}$ & $.858^{*}$ & $.313^{*}$ & $.405^{*}$ & $.420^{*}$ & $.471^{*}$ & $.625^{*}$ & - & & \\
\hline 9 Sosyal Zekâ & $.546^{*}$ & $.885^{*}$ & $.328^{*}$ & $.469^{*}$ & $.530^{*}$ & $.504^{*}$ & $.671^{*}$ & $.711^{*}$ & - & \\
\hline 10 Samimi G. & $.566^{*}$ & $.711^{*}$ & $.448^{*}$ & $.502^{*}$ & $.443^{*}$ & $.532^{*}$ & $.498^{*}$ & $.563^{*}$ & $.522^{*}$ & - \\
\hline Ortalama & 4,46 & 4,81 & 4,33 & 4,36 & 4,49 & 4,66 & 4,30 & 5,05 & 4,75 & 5,65 \\
\hline Standart Sapma & 0,67 & 1,04 & 0,72 & 0,71 & 0,89 & 0,84 & 1,20 & 1,29 & 1,25 & 1,21 \\
\hline
\end{tabular}

$N=325, * p<.001$

Tablo 2'den de izlenebileceği gibi katılımcıların psikolojik sermaye puan ortalamaları $4.46(S D=0.67)$ ve politik beceri puan ortalamaları 4.81 'dir $(S D=1.04)$. Yine Tablo 2 'den izlenebileceği gibi öğretmenlerin politik beceri düzeyleri ve psikolojik sermaye (toplam), iyimserlik, psikolojik dayanıklılık, umut ve özyeterlik boyutları arasında orta düzeyde anlamlı pozitif yönlü ilişkiler vardır $\left[\left(r_{\mathrm{PS}} \times \mathrm{PB}=.60 ; p<.001\right) ;\left(r_{\text {iyimserlik x } \mathrm{PB}}=.39 ; p<.001\right) ;\left(r_{\text {psikolojik }}\right.\right.$

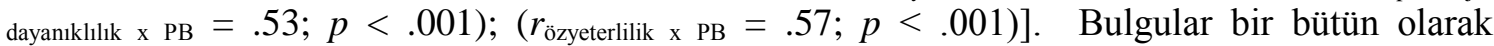
değerlendirildiğinde, katılımcıların politik beceri ve psikolojik sermaye düzeylerinin görece yüksek olduğu söylenebilir. Bununla birlikte öğretmenlerin politik becerileri ile psikolojik sermaye puanları arasında pozitif yönlü, anlamlı ve orta düzeyde bir ilişki olduğu da anlaşılmaktadır.

\subsection{Politik Becerinin Psikolojik Sermayeyi Yordama Gücüne İlişkin Bulgular}

Öğretmenlerin sahip oldukları psikolojik sermayenin, politik beceriyi ne oranda açıkladığını belirlemek amacıyla hiyerarşik çoklu regresyon analizinden yararlanılmıştır. Multicollinearity sorununu giderebilmek amacıyla, yordayıcı değişkenler ortalama çıkartma yöntemi (subtract the mean) kullanılarak standardize edilmiştir (Aiken ve West, 1991). Öğretmenlerin cinsiyetleri, medeni durumları, eğitim düzeyleri ve kıdemleri regresyon modelinin birinci basamağında eş değişken olarak girilmiş ve gölge (dummy) olarak kodlanmıştır. Ardından modelin ikinci, üçüncü, dördüncü ve beşinci basamaklarında psikolojik sermayenin dört altboyutu (i. e. iyimserlik, dayanıklılık, umut ve samimi görünme) asıl yordayıcı olarak ve ardış1k bir şekilde girilmiştir. Sonuçlar Tablo 2'de sunulmuştur. 
Tablo 3. Değişkenlerin politik beceriyi yordama düzeylerine ilişsin hiyerarşik regresyon sonuçları

\begin{tabular}{|c|c|c|c|c|c|c|c|c|c|c|}
\hline \multirow{3}{*}{$\begin{array}{l}\text { Yordayıcı } \\
\text { Değişkenler }\end{array}$} & \multicolumn{10}{|c|}{ Politik Beceri } \\
\hline & \multicolumn{2}{|c|}{ Model 1} & \multicolumn{2}{|c|}{ Model 2} & \multicolumn{2}{|c|}{ Model 3} & \multicolumn{2}{|c|}{ Model 4} & \multicolumn{2}{|c|}{ Model 5} \\
\hline & $\beta$ & $t$ & $\beta$ & $t$ & $\beta$ & $t$ & $\beta$ & $t$ & $\beta$ & $t$ \\
\hline \multicolumn{11}{|l|}{ Model 1} \\
\hline Cinsiyet & .071 & 1.212 & .076 & 1,415 & .063 & 1.298 & -.003 & 1.284 & .061 & 1.317 \\
\hline Medeni D. & .009 & .146 & .017 & .314 & .056 & 1.102 & .047 & 1.263 & .045 & .923 \\
\hline Eğitim D. & .083 & 1.483 & .070 & 1,367 & .019 & 1.028 & .061 & 1.027 & .030 & .676 \\
\hline Kidem & .070 & 1.130 & .089 & 1,556 & .048 & .367 & .063 & -.054 & .005 & .107 \\
\hline $\begin{array}{l}\text { Model } 2 \\
\text { İyimserlik }\end{array}$ & \multicolumn{5}{|c|}{ Model 2} & $3.804^{*}$ & .104 & 1.868 & .091 & 1.657 \\
\hline $\begin{array}{l}\text { Model } 3 \\
\text { Psikolojik D. }\end{array}$ & & & & & .441 & $8.326^{*}$ & .275 & $4.204^{*}$ & $.172^{*}$ & 2.449 \\
\hline $\begin{array}{l}\text { Model } 4 \\
\text { Umut }\end{array}$ & & & & & & & .295 & $4.136^{*}$ & $.162^{*}$ & 2.055 \\
\hline $\begin{array}{l}\text { Model } 5 \\
\text { Öz Yeterlilik }\end{array}$ & & & & & & & & & $.277^{*}$ & $3.628^{*}$ \\
\hline $\mathrm{R}^{2}$ & & & & & & & & & & \\
\hline $\mathrm{R}^{2}$ Change & & & & & & & & & & \\
\hline $\mathrm{F}$ & & & & $52^{*}$ & & $63^{*}$ & & & & \\
\hline
\end{tabular}

Tablo 3'den de izlenebileceği gibi uygulanan her adımda açıklanan varyans oranının arttığ 1 ve regresyon katsayı değerlerinin anlamlı çıktığı görülmüştür $[F(4-320)=24,455, p<.001$, $\mathrm{R} 2=.38$ ]. Model 1, demografik özelliklerin (cinsiyet, medeni durum, eğitim durumu ve kıdem) politik beceri üzerinde önemli bir yordayıcı olmadıklarını göstermiştir. Bununla birlikte demografik değişkenler politik becerideki toplam varyansın \% 2'sini açıklamaktadır. Model 2, iyimserlik değişkeninin politik beceri ile anlamlı bir şekilde ilişkili olduğunu göstermiştir $(\Delta \mathrm{R} 2=.174, \mathrm{p}<0.001)$. İyimserlik değişkeni analize eklendiğinde determinasyon katsayısını artırdığı ve tek başına politik beceri toplam varyansının \% 15'sini açıkladığı görülmüştür. Analize psikolojik dayanıklılık değişkeninin dahil edildiği Model 3'te psikolojik dayanıklılı̆̆ın politik becerinin anlamlı bir yordayıcısı olduğu $(\Delta \mathrm{R} 2=.322, \mathrm{p}<0.001)$ ve tek başına politik beceri toplam varyansının \% 15'ini açıkladığı görülmüştür. Model 4'te analize giren umut değişkeninin de politik becerinin anlamlı bir yordayıcısı olduğu saptanmıştır $(\Delta \mathrm{R} 2=.357, \mathrm{p}<0.001)$. Umut değişkeni tek başına politik beceri toplam varyansının \%3'ünü açıklamaktadır. Son adım olan Model 5'te öz yeterlilik analize dahil edilmiş ve politik beceri üzerinde anlamlı bir etkiye sahip olduğu görülmüştür $(\Delta \mathrm{R} 2=.382, \mathrm{p}<0.001)$. Aynı zamanda özyeterlilik değişkeninin tek başına politik beceri toplam varyansının \% 3'ünü açıkladığı görülmüştür. Elde edilen sonuçlardan, değişkenlerin hepsinin toplamda politik beceri toplam varyansının \% 38'ini açıkladı̆̆ görülmektedir.

\section{TARTIŞMA ve SONUÇ}

$\mathrm{Bu}$ araştırmada Türkiye'deki ilköğretim okullarında görev yapmakta olan öğretmen görüşlerine dayalı olarak psikolojik sermaye ile politik beceri arasındaki ilişki incelenmiştir. Bu kapsamda Ankara ili merkez ilçelerindeki 15 ilköğretim okulunda görev yapan 325 öğretmenin görüşüne başvurulmuştur. Araştırmada öncelikle katılımcıların psikolojik sermaye ve politik becerilerinin ne düzeyde olduğu sorusuna yanıt aranmıştır.

Bulgular, katılımcıların politik beceri düzeylerinin görece yüksek olduğuna işaret etmektedir. Bu bulgu Cingöz’ün (2013), sanayi kuruluşlarında gerçekleştirmiş olduğu çalışma 
bulguları ile uyumludur. Sözü edilen çalışmada da katılımcıların politik becerilerinin orta düzeyin üstünde olduğu belirlenmiştir. Katılımcıların, politik becerilerinin görece yüksek çıkmasının olası bir nedeni, "sosyal arzulanırlık" olabilir. Nitekim kendini değerlendirme ölçeklerinde, sosyal arzulanırlık sorununun yaşanabileceği rapor edilmektedir (Murphy ve Davidshover, 1991, s. 173). Sosyal arzulanırlık, "katılımcılıların, ölçek maddelerine genel olarak toplumun kabul göstereceği biçimde yanıt vermeleri" şeklinde tanımlanmaktadır. Katılımcıların politik becerilerinin yüksek düzeyde belirlenmiş olmasının bir başka nedeni ise öz-yeterlik algılarının yüksek olması olabilir. Öğretmenlerin öz-yeterlik inançları üzerine yürütülmüş çalışmalarda, katılımcıların öz-yeterlik inançlarının yüksek olduğu rapor edilmiştir (Ekici, 2006; Taşkın ve Haciömeroğlu, 2010). Örneğin, ilköğretim okullarında görev yapan sınıf öğretmenleri üzerinde yürüttüğü çalışmasında da Eker (2014), katılımcıların öz-yeterlik algılarının 'yeterli' olduğunu saptamıştır. Sonuç olarak bizim araştırmamızda karşılaştığımız bulgunun, benzer çalışmalarla uyumlu olduğu görülmüştür.

Araştırmada ayrıca katılımcıların psikolojik sermaye düzeylerinin görece yüksek olduğu da belirlenmiştir. Bu bulgu çeşitli sektörlerde çalışan katılımcıların psikolojik sermayeleri üzerine odaklan benzer bir çalışmanın bulguları ile paraleldir (Erkuş ve Fındıklı, 2013). Sözü edilen çalışmada da katılımcıların psikolojik sermaye ölçeği ve ölçeğin boyutlarından aldıkları puan ortalamalarının yüksek olduğu belirlenmiştir. Yine benzer bir çalışma yürütmüşs olan Kaya, Balay ve Demirci (2014), araştırmalarında öğretmenlerin psikolojik sermayelerinin orta düzeyde olduğunu saptamışlardır. Katılımcıların psikolojik sermaye düzeylerini yüksek algılamaları, onların iş yerinde yaşamaları muhtemel olumsuzluklarla daha etkili baş edebileceklerine ilişkin bir inanç taşıdıkları şeklinde değerlendirilebilir. Bu görüş ile uyumlu olarak, bir araştırmada psikolojik sermayenin, çalışanların iş yerinde yaşadıkları stresle daha etkili şekilde baş edebildiklerini ve işten ayrılma niyetlerini azalttığını ortaya çıkartmıştır (Avey, Luthans ve Jensen, 2009). Nitekim bazı çalışmalarda psikolojik sermayesi yüksek çalışanların, görece daha fazla iş doyumu ve işe bağl1lı gösterdikleri belirlenmiştir (Luthans ve diğerleri, 2007; Luthans, Norman, Avolio ve Avey, 2008).

Araştırmada psikolojik sermaye ile politik beceriler arasında pozitif yönde, orta düzeyde ve istatistiksel olarak anlamlı korelasyon olduğu saptanmıştır. Bu bulgu, katılımcıların psikolojik sermayeleri ile politik becerilerinin önemli düzeyde ilişki içerisinde olduğunun bir göstergesi olarak değerlendirilebilir. Başka bir deyişle, öğretmenlerin psikolojik sermayeleri yükselme eğilimi gösterdikçe, politik beceri taşıdıklarına ilişkin inançları da artmaktadır. Bu bulgu benzer çalışma bulgularını desteklemektedir. Örneğin benzer bir çalışmada psikolojik sermaye düzeyi yüksek çalışanların, daha fazla oranda örgütsel süreçler üzerinde etki gösterebilecekleri yönünde inanç taşıdıkları keşfedilmiştir (Avey, Wernsing ve Luthans, 2008). Ayrıca bir başka çalışmada psikolojik sermaye düzeyi yüksek çalışanların örgütsel vatandaşlık davranış eğiliminin de yüksek olduğu belirlenmiştir (Zhong, 2007). Bir bütün olarak değerlendirildiğinde, katılımcıların psikolojik sermayelerinin yüksek olduğuna ilişkin görüşleri, onların aynı zamanda görev yaptıkları okullarda, örgütsel süreçler üzerinde görece etki sahibi olabilecekleri yönünde bir alg1 içerisinde oldukları şeklinde de değerlendirilebilir. Nitekim araştırma bulguları katılımcıların psikolojik sermayeye ilişkin algılarının artması ile politik becerilerinin de arttığına ilişkin görece kanıt sunmaktadır.

$\mathrm{Bu}$ araştırmada son olarak, psikolojik sermayenin, öğretmenlerin politik becerilerini ne düzeyde yordadığına ilişkin analizler yapılmıştır. Bu amaçla gerçekleştirilen hiyerarşik çoklu regresyon analizinin birinci evresinde, demografik değişkenlerin, politik beceri üzerinde önemli bir etkiye sahip olmadığ 1 belirlenmiştir. Buna göre katılımcıların cinsiyeti, medeni durumu, kıdemi ve eğitim düzeyi, politik becerinin anlamlı bir yordayıcı değildir. Ancak, hiyerarşik regresyonun ikinci ve onu izleyen diğer evrelerinde, psikolojik sermaye ölçeğinin dört alt boyutunun, ayrı ayrı ve kademeli bir şekilde politik becerinin anlamlı bir yordayıcısı oldukları belirlenmiştir. Buna göre, politik becerideki değişkenliğin görece bir bölümü (\% $\left.38^{\prime} i\right)$, 
katılımcıların psikolojik sermayeleri tarafindan açıklanmaktadır. Başka bir ifadeyle, katılımcıların psikolojik sermayeleri, onların politik becerilerini anlamlı şekilde yordamaktadır. $\mathrm{Bu}$ bulgu benzer çalışmalarla uyumludur. Örneğin psikolojik sermaye üzerine yapılmış olan bir meta-analiz çalışmasında psikolojik sermayenin çalışanların işe yönelik tutumları, davranışları ve performansları üzerinde önemli bir etkiye sahip olduğu belirlenmiştir (Avey, Reichard, Luthans ve Mhatre, 2011). Dolayısıyla, bu çalışmada son olarak alan yazınla uyumlu bir şekilde, psikolojik sermayenin öğretmen örnekleminde, politik beceriyi açıklayan önemli bir etmen olduğu genel sonucuna ulaşılmıştır.

\section{5. ÖNERILLER}

$\mathrm{Bu}$ araştırma Ankara ili merkez ilçesinde yer alan 15 okulda görev yapan 325 öğretmenin görüşleri ile sınırlıdır. Bu nedenle, psikolojik sermaye ile politik beceri arasındaki ilişkinin daha büyük örneklemler üzerinde yürütülmesinin alan yazına daha fazla katk1 sunabileceği düşünülmektedir. Ayrıca, benzer çalışmaların, orta öğretim ve yüksek öğretim gibi farklı eğitim kademelerinde de yürütülmesi, iki değişken arasındaki ilişkin farklı eğitim kademelerindeki görünümlerinin anlaşılmasına 1şı tutabilir. Politik beceri konusunun eğitim örgütlerindeki görünümleri üzerinde yapılan çalışmalar azdır. Bu nedenle, politik becerinin nedenlerini ve olası sonuçlarını başka değişkenlerle birlikte incelemek, bu değişkenin doğasının bütüncül bir biçimde kavranmasına katkı sunabilir. Bu amaçla, ileride derinlemesine analize olanak tanıyan nitel çalışmalar yapılabilir. Bunun yanında, çalışma sonuçlarına göre öğretmenlerin psikolojik sermayesinin politik becerlerini üzerindeki etkili olduğu görülmüştür. Öğretmenlerin politik becerilerini geliştirmek ve böylelikle okuldaki stres, başarısızlık, çatışma gibi olumsuz durumlarla başedebilmesini sağlamak amacıyla psikolojik sermaye düzeylerinin yükseltilmesi gerektiği söylenebilir. Bunun için, müdürler tarafından öğretmenlere daha fazla insiyatif verilmesi, kendilerini geliştirebilecek ve gerçekleştirebilecek imkanların sağlanması, okulda etkili iletişimi sağlayacak kültürün oluşturulması gibi önlemler alınabilir.

\section{KAYNAKLAR}

Ahearn, K. K., Ferris, G. R., Hochwarter, W. A., Douglas, C. \& Ammeter, A. P. (2004) Leader political skill and team performance. Journal of Management, 30, 309-327.

Aiken, L. S., \& West, S. G. (1991). Multiple regression: Testing and interpreting interactions. Newbury Park, CA: Sage.

Akçay, V. H. (2012). Pozitif psikolojik sermayenin iş tatmini ile ilişkisi. Kahramanmaraş Sütçü İmam Üniversitesi İktisadi ve İdari Bilimler Dergisi, 1, 123-140.

Avey, J. B., Luthans, F. \& Jensen, S. (2009). Psychological capital: A positive resource for combating employee stres and turnover. Human Resource Management, 48(5), 677-693.

Avey, J. B., Reichard, R. J., Luthans, F., \& Mhatre, K. H. (2011). Meta-analysis of positive psychological capital on employee attitudes, behaviors and, performance. Human Resource Development Quarterly, 22(2), 127-152.

Avey, J . B., Wernsing, T. S., \& Luthans, F. (2008). Can possitive employees help positive organizational change? Impact of psychological capital and emotions on relevant attitudes and behaviors. Journal of Applied Behavioral Sciences, 44(1), 48-70.

Cingöz, A. (2013). Politik yetenekler ve öz-yönlendirmenin (kendini kurgulamanın) algılanan kariyer başarısı üzerindeki etkisini belirlemeye yönelik bir araştırma. Selçuk Üniversitesi İktisadi ve İdari Bilimler Dergisi, 13(26), 153-179.

Çetin, F. ve Basım, H. N. (2012). Örgütsel psikolojik sermaye: Bir ölçek uyarlama çalışması. Amme İdaresi Dergisi, 45(1), 121-137.

Çetin, F., Şeşen, H. ve Basım, H. N. (2013). Örgütsel psikolojik sermayenin tükenmişlik sürecine etkileri: Kamu sektöründe bir araştırma. Anadolu Üniversitesi Sosyal Bilimler Dergisi, 13(3), 95-108. 
Douglas, C., \& Ammeter,A. P. (2004). An examination of leader political skill and its effect on ratings of leader effectiveness. The Leadership Quarterly, 15, 537- 550.

Ehrenberg, R. G., \& Brewer, D. J. (1994). Do school and teacher characteristics matter? Evidence from high schools and beyond. Economics of Education Review, 13(1), 1-17.

Eker, C. (2014). Sınıf öğretmenlerinin öz-yeterlik inanç düzeyleri üzerine bir araştırma. Uşak Üniversitesi Sosyal Bilimler Dergisi, 7(1), 162-178.

Ekici, G. (2006). Meslek lisesi öğretmenlerinin öğretmen öz-yeterlik inançları üzerine bir araştırma. Eurasian Journal of Educational Research, 24, 87-96.

Erkmen, T. ve Esen, E. (2012). Psikolojik sermaye konusunda 2003-2011 yıllarında yapılan çalışmaların kategorik olarak incelenmesi. Mustafa Kemal Üniversitesi Sosyal Bilimler Enstitüsü Dergisi, 9(19), 89-103.

Erkmen, T. ve Esen, E. (2013). Psikolojik sermaye ölçeğinin geçerlilik ve güvenilirlik çalışması. Marmara Üniversitesi Sosyal Bilimler Enstitüsü Öneri Dergisi.

Erkuş, A. ve Fındıkl1, M. A. (2013). Psikolojik sermayenin iş tatmini, iş performansı ve işten ayrılma niyeti üzerindeki etkisine yönelik bir araştırma. İstanbul Üniversitesi Işletme Fakültesi Dergisi, 42(2), 302-318.

Howard, S., \& Johnson, B. (2004). Resilient teacher: resisting stress and burnout. Social Psychological of Education, 7, 399-420.

Jina, S. Y. (2002). Teacher characteristics as predictors of teacher-student relationships: Stress, negative affect, and self-efficacy. Social Behavior and Personality: an international journal, 30(5), 485-493.

Kaplan, M. ve Biçkes, D., M. (2013). Psikolojik sermaye ile iş tatmini arasındaki ilişkinin analizi: Otel işletmelerinde yapılan bir araştırma. Yönetim ve Ekonomi Dergisi, 20(2), 233-242.

Kaya, A., Balay, R. ve Demirci, Z. (2014). Ortaöğretimde görev yapan öğretmenlerin psikolojik sermaye düzeylerinin incelenmesi: Şanlıurfa örneği. Elektronik Sosyal Bilimler Dergisi, 48.

Keleş, H., N. (2011). Pozitif psikolojik sermaye: Tanımı, bileşenleri ve örgüt yönetimine etkileri. Organizasyon ve Yönetim Bilimleri Dergisi, 3(2), 343-350.

Keser, S. ve Kocabaş, İ. (2014). İlköğretim okulu yöneticilerinin otantik liderlik ve psikolojik sermaye özelliklerinin karş1laştırılması. Kuram ve Uygulamada Eğitim Yönetimi, 20(1), 1-22.

King, J. (2003). Teacher Quality: Understanding the Effectiveness of Teacher Attributes. Washington: Economic Policy Institute.

Luthans, F., Avey, J., B., Avolio, B., J., Norman, S., M. ve Combs, G., M. (2006). Psychological capital development: Toward a microintervention. Journal of Organizational Behavior, 27, 387-393.

Luthans, F., Avolio, B., J., Avey, J., B., Norman, S., M. (2007). Positive psychological capital: Measurement and relationship with performance and satisfaction. Personnel Psychology, 60, 541-572.

Luthans, F., Norman, S. M., Avolio, B. J., \& Avey, J. B. (2008). The mediating role of psychological capital in the supportive organizational climate-employee performance relationship. Journal of Organizational Behavior, 29, 219-238.

Murphy, K. R. \& Davidshofer, C. O. (1991). Psychological Testing: Principals and Applications. New Jersey: Prentice Hall.

Oruç, E. ve Özen Kutanis, R. (2015). Pozitif psikolojik sermayenin örgüt içi politik davranışlara etkisi: akademisyenler üzerine bir araştırma. İşletme Araştırmaları Dergisi, 7(3), 36-58.

Özen Kutanis, R. ve Oruç, E. (2014). Pozitif örgütsel davranış ve pozitif psikolojik sermaye üzerine kavramsal bir inceleme. The Journal of Happiness \& Well-Being, 2(2), 145-159.

Özer, P., Ö., Topaloğlu, T., ve Ö., N., T.,Özmen (2013). Destekleyici örgüt ikliminin, psikolojik sermaye ile iş doyumu ilişkisinde düzenleyici etkisi. Ege Akademik Baklş, 13(4), 437-447.

Parkay, F. W., Greenwood, G., Olejnik, S., \& Proller, N. (1988). A study of the relationships among teacher efficacy, locus of control, and stress. Journal of Research \& Development in Education, 21(4), 13-22.

Taliadorou, N., \& Pashiardis, P. (2012). Examing the relationship of emotional intelligence and political skill with effective educational leadership styles. Retreived from http://www.icsei.net/icsei2011/Full\%20Papers/0030.pdf

Taşkın, Ç. Ş. ve Hacı̈̈meroğlu, G. (2010). Öğretmen özyeterlik inanç ölçeğinin Türkçe’ye uyarlaması ve sınıf öğretmeni adaylarının özyeterlik inançları. Buca Eğitim Fakültesi Dergisi, 27, 63-75.

Tösten, R. ve Özgan, H. (2014). Pozitif psikolojik sermaye ölçeği: geçerlik ve güvenirlik çalışması. Ekev Akademi Dergisi, 18(59).

Wayne, A. J., \& Youngs, P. (2003). Teacher characteristics and student achievement gains: a review. Review of Educational Research, 73(1), 89-122.

Woolfolk, A. E., \& Hoy, W. K. (1990). Prospective teachers' sense of efficacy and beliefs about control. Journal of Educational Psychology, 82, 81-91. 
Zhong, L. (2007). Effects of psychological capital on employees' job performance, organizational commitment and organizational citizenship behavior. Acta Psychologica Sinica, 39, 328-334.

\section{Extended Abstract}

School factors effect student achievement as much as students' personal, family and socioeconomical factors. One of the most important school factors that effects student achievement is teacher. Investigating teachers' features apart from school climate is insufficient to understand teachers' performance and behaviors. Within this scope, it is significant to investigate teachers' behaviors according to micro political school climate and culture of school. It can be said that teachers are political actors at school on the assumption that school is an organization where micro policies are dominant. Therefore, teachers are supposed to have political skill to achieve personal and organizational goals. Political skill consists of four sub dimensions that are social astuteness, interpersonal influence, networking ability and apparent sincerity. Psychological capital, which is related to individual's positive psychological state of his/her improvement, is also important for teachers' personal and organizational achievement. Psychological capital that focuses on teachers' positive features consists of four sub dimensions that are hope, optimism, self-efficacy and resilience.

In the national literature, it can be seen that psychological capital has been investigated in various aspects. Those studies are mostly on what psychological capital is and the effects of psychological capital on organizations. However, the studies that focus on psychological capital of teachers in educational organizations are limited. Moreover, in the national literature, there is no study on the relationship between psychological capital and political skill of teachers in educational organizations. Therefore, the aim of this study was to investigate how the relationship between psychological capital and political skill based on teachers' opinions.

The study was designed as a survey study. The collected data of the study was analyzed with quantitative method. The study was conducted with voluntary participation of 325 teachers working in 15 primary and secondary schools in the district of Ankara Altındağ. 69,5\% of the participants were female and $30,5 \%$ of them were male. Besides, $74,5 \%$ of the participants were married and $25,5 \%$ of them were single. Of these participants, $86,8 \%$ had bachelor's degree and $13,2 \%$ had postgraduate degree. In the present study, 'Political Skill Inventory-PSI', originally developed by Ferris et al (2005), and 'Psychological Capital Questionnaire-PSQ' developed by Luthans et al (2007) were used to collect data. PSI is an instrument that covers 18 items and four dimensions and PSQ is an instrument that consists of 24 items and four dimensions. The Cronbach alpha coefficient of PSI was found in the study as .94 and the Cronbach alpha coefficient of PSQ was .91. The collected data was analyzed via Pearson correlation, hierarchical multiple regression, mean, standard deviation and percentage.

The results of the study showed that the level of teachers' political skill $(M=4.81, S D=1.04)$ and psychological capital $(M=4.46, S D=0.67)$ were relatively high. It was also determined that there was a positive, medium level and statistically significant relation between political skill and psychological capital of the teachers $\left[\left(r_{\mathrm{PC} \times \mathrm{PS}}=.60 ; p<.001\right) ;\left(r_{\mathrm{optimism} \times \mathrm{PS}}=.39 ; p<.001\right) ;\left(r_{\text {resilience } \mathrm{PS}}=.53 ; p<.001\right)\right.$; $\left.\left(r_{\text {self-efficacy x PS }}=.57 ; p<.001\right)\right]$. Besides, the results showed that demographic features of teachers (gender, level of education, marital status and seniority) didn't affect their political skill. The demographic features of the participants predicted $2 \%$ of their political skill. On the other hand, the overall regression model was significant, $[\mathrm{F}(4-320)=24,455, \mathrm{p}<.001, \mathrm{R} 2=.38]$ with a significant increase in R2 in each step. All subdimensions of psychological capital were significant predictors of political skill. The results showed that optimism $(\Delta \mathrm{R} 2=.174, \mathrm{p}<0.001)$, resilience $(\Delta \mathrm{R} 2=.322, \mathrm{p}<0.001)$, hope $(\Delta \mathrm{R} 2=.357, \mathrm{p}<0.001)$ and selfefficacy $(\Delta \mathrm{R} 2=.382, \mathrm{p}<0.001)$ were separately significant predictors of political skill. It was also determined that all the dimensions of psychological capital totally predict $38 \%$ of the variance of political skill.

The results of the study revealed that there was a significant relation between political skill and psychological capital of teachers. It can be concluded from this result that the higher teachers' psychological capital is, the more they believe that they have political skill. Moreover, the results showed that teachers' psychological capital is a significant predictor of their political skill. It is suggested that this study to be repeated with larger samples in educational organizations. Moreover, conducting similar studies investigating the relation between these two variables at different levels of education such as 
secondary and higher education can contribute to the literature. The studies on political skill in educational organizations are very limited. Therefore, investigating the reasons and possible results of political skill in relation with different variables can contribute to realizing this variable in an integrated way. It can be suggested that qualitative studies can be carried out on political skill. 